\title{
Fenton-type processes triggered by titanomagnetite for the degradation of phenol as model pollutant
}

\author{
Stefano Bertinetti ${ }^{a}$, Khalil Hanna ${ }^{\mathrm{b}}$, Marco Minella ${ }^{\mathrm{a}}$, Claudio Minero ${ }^{\mathrm{a}}$, Davide Vione ${ }^{\mathrm{a}, *}$ \\ ${ }^{a}$ Dipartimento di Chimica, Università di Torino, Via Pietro Giuria 5, 10125 Torino, Italy, Tel. +39-011-6705296; \\ Fax:+39-011-6705242; emails: davide.vione@unito.it (D. Vione), stefano.bertinetti@edu.unito.it (S. Bertinetti), \\ marco.minella@unito.it (M. Minella), claudio.minero@unito.it (C. Minero) \\ ${ }^{b}$ Ecole Nationale Supérieure de Chimie de Rennes, CNRS, UMR 6226, 11 Allée de Beaulieu, CS 50837, 35708 Rennes Cedex 7, \\ France, email: khalil.hanna@ensc-rennes.fr
}

Received 15 October 2018; Accepted 14 January 2019

\begin{abstract}
A B S T R A C T
Heterogeneous catalysts for the oxidation of toxic compounds are extremely important for many applications including environmental remediation. Here, we assessed the ability of Ti-substituted magnetite, i.e., titanomagnetite $\left(\mathrm{Fe}_{(2-2 x)}^{\mathrm{III}} \mathrm{Fe}_{(1+x)}^{\mathrm{II}} \mathrm{Ti}_{\mathrm{x}} \mathrm{O}_{4}\right)$ to promote Fenton-like heterogeneous reactions. Two titanomagnetites with $x$ values respectively equal to 0.25 (TM0.25) and 0.75 (TM0.75), as well as unsubstituted magnetite $(\mathrm{M}, x=0)$ were tested for the degradation of phenol under different conditions. Kinetic assessments over $1 \mathrm{~h}$ reaction time showed that all the studied systems had the best performance at $\mathrm{pH}$ 3. This is the typical, optimal $\mathrm{pH}$ value of the Fenton reaction. Moreover, titanomagnetite-based systems were active at low loading and afforded the application of relatively low $\mathrm{H}_{2} \mathrm{O}_{2}$ doses. The titanomagnetites had lower ability than magnetite to induce phenol degradation at $\mathrm{pH}>3$. However, presumably because of the higher Fe(II) content, TM0.75 was less susceptible than M or TM0.25 to the loss in reactivity caused by air exposure. TM0.75 can thus be handled in ambient systems or $\mathrm{O}_{2}$-containing environments, which may be a key advantage from an application point of view.
\end{abstract}

Keywords: Tertiary water treatment; Advanced oxidation processes; Dissolved Fe; Heterogeneous Fenton reaction; Hydrogen peroxide

\section{Introduction}

Water is one of the foundations of life, and the international community has included the access to safe water among the fundamental human rights (United Nations General Assembly, Resolution 64/292). However, because of the irregular distribution of water resources on our planet and their incorrect management, this right is often not warranted. The protection of rivers, lakes and groundwater from pollution and a correct water use should have central importance in environmental policies, also to improve the resilience of human communities to global changes [1]. A major challenge is the reuse of sewage water to reduce the dependence on natural water sources. However, reuse has

\footnotetext{
* Corresponding author.
}

to face the occurrence in wastewater of some substances that are recalcitrant to traditional sewage treatment [2]. A possible way to achieve the elimination of recalcitrant (poorly biodegradable and highly stable) compounds consists in the so-called Advanced Oxidation Processes (AOPs) [3-6], which are a set of techniques based on the formation of strongly reactive transient species such as the hydroxyl radical, ${ }^{\circ} \mathrm{OH}$ [7]. In the framework of several AOPs ${ }^{\circ} \mathrm{OH}$ is produced under irradiation, often with the use of light-absorbing semiconductor metal oxides [4-7], but dark ${ }^{\circ} \mathrm{OH}$ generation is also extensively exploited [3]. Typically, the transient species used in AOPs have elevated oxidizing capacity (the - $\mathrm{OH}$ standard electrode potentials are $\mathrm{E}^{0}{ }^{\bullet} \mathrm{OH} / \mathrm{OH}^{-}=1.90 \mathrm{~V}$ vs. $\mathrm{NHE}$, and $\mathrm{E}^{0} \cdot \mathrm{OH}, \mathrm{H}^{+} / \mathrm{H}_{2} \mathrm{O}=2.73 \mathrm{~V}$ vs. NHE [8]) and are often able to promote total mineralization of pollutants, 
i.e., their complete conversion into $\mathrm{CO}_{2}, \mathrm{H}_{2} \mathrm{O}$ and inorganic acids $\left(\mathrm{HCl}, \mathrm{HNO}_{3}, \mathrm{H}_{2} \mathrm{SO}_{4}\right)$. As an alternative the transient species may modify the pollutants structure highly enough to increase biodegradability, thereby enabling the application after the AOP stage of more traditional techniques such as activated-sludge degradation [9-11]. The combination of AOPs with traditional biological treatments can in fact reduce the overall costs related to reagents and energy $[12,13]$. Among the different AOPs, the Fenton reaction is interesting because of its ease of operation and relatively low costs. In the classic view of Fenton processes, ${ }^{\circ} \mathrm{OH}$ and other oxidizing agents are produced upon reaction between $\mathrm{Fe}(\mathrm{II})$ and $\mathrm{H}_{2} \mathrm{O}_{2}$ (Reaction (1)) [14]:

$\mathrm{Fe}(\mathrm{II})+\mathrm{H}_{2} \mathrm{O}_{2} \rightarrow \mathrm{Fe}(\mathrm{III})+\mathrm{OH}^{-}+{ }^{\bullet} \mathrm{OH}$

An excess of $\mathrm{H}_{2} \mathrm{O}_{2}$ over $\mathrm{Fe}(\mathrm{II})$ is usually employed, thus $\mathrm{Fe}(\mathrm{III})$ can be reduced back to $\mathrm{Fe}(\mathrm{II})$ and regenerate the active species for the decomposition of $\mathrm{H}_{2} \mathrm{O}_{2}$ (Reactions (2)-(4)) [14]:

$$
\begin{aligned}
& \mathrm{Fe}(\mathrm{III})+\mathrm{H}_{2} \mathrm{O}_{2} \rightarrow \mathrm{Fe}(\mathrm{II})+\mathrm{H}^{+}+\mathrm{HO}_{2} \cdot \\
& \mathrm{Fe}(\mathrm{III})+\mathrm{HO}_{2}^{\cdot} \rightarrow \mathrm{Fe}(\mathrm{II})+\mathrm{H}^{+}+\mathrm{O}_{2} \\
& \mathrm{Fe}(\mathrm{III})+\mathrm{O}_{2}^{\cdot-} \rightarrow \mathrm{Fe}(\mathrm{II})+\mathrm{O}_{2} \\
& \mathrm{Fe}(\mathrm{II})+\cdot{ }^{\cdot} \mathrm{OH} \rightarrow \mathrm{Fe}(\mathrm{III})+\mathrm{OH}^{-} \\
& \mathrm{H}_{2} \mathrm{O}_{2}+{ }^{\cdot} \mathrm{OH} \rightarrow \mathrm{HO}_{2}^{\cdot}+\mathrm{OH}^{-}
\end{aligned}
$$

Because reactions (2)-(4) are slower than reaction (1), Fe(III) is usually the prevailing Fe species in solution at sufficiently long reaction times. The optimal $\mathrm{pH}$ value for the Fenton reaction is often around 3 [15], which means that the $\mathrm{pH}$ of many wastewaters needs two corrections, the first before the Fenton treatment (to reach the optimal pH conditions) and the second after treatment, before discharge into the receiving water body. The latter $\mathrm{pH}$ correction causes precipitation of amorphous ferric oxyhydroxides, which can be minimized (but not totally eliminated) by using a catalytic concentration of $\mathrm{Fe}(\mathrm{II})$, with a peroxide-to-iron concentration ratio in the order of 100-1,000 [14]. This latter approach extensively exploits reactions (2)-(4) to regenerate $\mathrm{Fe}(\mathrm{II})$, but it leaves an excess of potentially toxic $\mathrm{H}_{2} \mathrm{O}_{2}$ at the end of the treatment. $\mathrm{H}_{2} \mathrm{O}_{2}$ should thus be monitored and eliminated if needed, i.e., unless it is convenient to use $\mathrm{H}_{2} \mathrm{O}_{2}$ for water disinfection. Furthermore, $\mathrm{Fe}(\mathrm{II})$ and $\mathrm{H}_{2} \mathrm{O}_{2}$ react with ${ }^{\circ} \mathrm{OH}$ (Reactions (5) and (6)) in competition with the pollutant(s) to be eliminated $[16,17]$, and the relevant processes have to be minimized by keeping the concentration values of $\mathrm{H}_{2} \mathrm{O}_{2}$ and $\mathrm{Fe}(\mathrm{II})$ low. In case of high pollutants concentrations requiring high doses of reagents, to limit the scavenging processes it is better to add the reagents multiple times instead of carrying out a single large addition [10].

While the above reactions occur at low $\mathrm{pH}$ values, under $\sim$ neutral conditions one has additional processes that could compete with the production of ${ }^{\bullet} \mathrm{OH}$. In particular, there is formation of high-valence iron species (e.g., the ferryl ion $\mathrm{FeO}^{2+}$ ) that have lower oxidation potential than ${ }^{\circ} \mathrm{OH}$, but may produce the same transformation intermediates as $\mathrm{OH}$ in the presence of easily oxidized compounds [14,18].

When using soluble Fe(II,III) salts as iron source, the system initially contains dissolved Fe species and one thus speaks of homogeneous Fenton reaction. In contrast, in the heterogeneous Fenton processes the iron source is a water-suspended solid that can be easily recovered after treatment, in particular if it has magnetic properties [19-24]. In this work we used magnetite (M) and magnetite substituted with titanium (titanomagnetite, TM0.25 and TM0.75) for heterogeneous Fenton experiments aimed at the degradation of phenol as model pollutant. Titanomagnetite alone (without $\mathrm{H}_{2} \mathrm{O}_{2}$ ) is active in the reduction of nitroaromatic compounds, and its reactivity is highly affected by the $\mathrm{Fe}(\mathrm{II}) / \mathrm{Fe}(\mathrm{III})$ ratio [25]. The amount of titanium in the titanomagnetite influences the $\mathrm{Fe}(\mathrm{II}) / \mathrm{Fe}(\mathrm{III})$ ratio in the lattice structure, because of the need of preserving the electroneutrality of the material after insertion of Ti(IV) in the crystalline structure. The Fe(II) content and magnetic properties of titanomagnetite suggest that it is a potentially useful heterogeneous catalyst in the Fenton reaction. Indeed, titanomagnetite has been shown to remove methylene blue [26] and tetrabromobisphenol A [27] from aqueous solutions. This work is the first study, to our knowledge, that comprehensively takes into account the effects of $\mathrm{pH}$, substrate and $\mathrm{H}_{2} \mathrm{O}_{2}$ concentration, as well as of aging time on the Fenton reactivity of titanomagnetite, and compares it with that of magnetite. Moreover, the monitoring of the time evolution of $\mathrm{H}_{2} \mathrm{O}_{2}, \mathrm{Fe}(\mathrm{II})$ and $\mathrm{Fe}(\mathrm{III})$ in the process allowed for mechanistic inferences to be drawn.

Among the important reaction parameters to be optimized, the $\mathrm{pH}$ value plays a key role. The homogeneous Fenton process quickly loses efficiency when $\mathrm{pH}$ is raised above the optimum value of 3 [15], largely because of solubility issues with $\mathrm{Fe}(\mathrm{III})$ species that undergo a progressively slower reduction to $\mathrm{Fe}(\mathrm{II})$ as the $\mathrm{pH}$ increases [14]. In the case of heterogeneous Fenton, the need to have Fe(III) in the dissolved form is less critical and one may have non-negligible reactivity at relatively high $\mathrm{pH}$ values [28]. In some cases the operational $\mathrm{pH}$ can be extended to higher values upon addition of $\mathrm{Fe}$ (III) chelating agents (e.g., oxalate, citrate and ethylenediamminotetraacetic acid, EDTA) [29,30], but it is important to check that the concentration of total dissolved $\mathrm{Fe}$ at the end of the process does not exceed the limits for wastewater discharge [28].

Phenol was here chosen as model pollutant, because it has been extensively used in previous works [28] so that it is possible to compare the Fenton performance of titanomagnetite with that of other heterogeneous systems such as, most notably, zero-valent iron (ZVI). Moreover, phenol is an actual pollutant emitted by oil refineries, coal gasification plants, and plants that produce metallurgical coke $[31,32]$.

\section{Experimental setup}

\subsection{Reagents and materials}

Phenol (purity grade 99\%), $\mathrm{HClO}_{4}(70 \% \mathrm{w} / \mathrm{w}), \mathrm{NaOH}$ $(\geq 90 \%)$, methanol (gradient grade), $\mathrm{H}_{2} \mathrm{SO}_{4}(96 \% \mathrm{w} / \mathrm{w})$, 
$\mathrm{H}_{3} \mathrm{PO}_{4}\left(85 \%\right.$ w/w), $\mathrm{Fe}\left(\mathrm{NO}_{3}\right)_{3} \times 9 \quad \mathrm{H}_{2} \mathrm{O}(99 \%)$, ampyrone (4-Amino-2,3-dimethyl-1-phenyl-3-pyrazol-5-one; reagent grade), $\mathrm{NaH}_{2} \mathrm{PO}_{4}(\geq 99.9 \%)$ and horseradish peroxidase were purchased from Sigma-Aldrich, KSCN ( $\geq 98 \%)$ and $\mathrm{FeSO}_{4} \times 7 \quad \mathrm{H}_{2} \mathrm{O}(99.5 \%)$ from Merck, $\mathrm{Na}_{2} \mathrm{HPO}_{4}(\geq 98 \%)$ and 1,10-phenanthroline (>99\%) from Aldrich, $\mathrm{H}_{2} \mathrm{O}_{2}(30 \% \mathrm{w} / \mathrm{v})$ from Applichem PanReac. These reagents were used as received, without further purification. The water used was of Milli-Q quality.

The unsubstituted magnetite $\left(\mathrm{Fe}_{3} \mathrm{O}_{4}, \mathrm{M}\right)$ and titanium-substituted magnetites $\left(\mathrm{Fe}_{3-\mathrm{x}} \mathrm{Ti}_{\mathrm{x}} \mathrm{O}_{4} ; x=0.25\right.$ and 0.75 to give the acronyms TM0.25 and TM0.75, respectively, with $x$ as per the $\mathrm{FeCl}_{2}: \mathrm{FeCl}_{3}: \mathrm{TiCl}_{4}$ molar ratios used in the synthesis, vide infra) were synthesized applying the precipitation method described in Pearce et al. [33]. Briefly, a $0.3 \mathrm{~mol} \mathrm{~L}^{-1} \mathrm{HCl}$ solution containing $(1+x) \mathrm{mol} \mathrm{L}^{-1} \mathrm{FeCl}_{2}$ and $(2-2 x) \mathrm{mol} \mathrm{L}^{-1} \mathrm{FeCl}_{3}$ was prepared first, followed by a dropwise addition of $\mathrm{x} \mathrm{mol} \mathrm{L}^{-1}$ $\mathrm{TiCl}_{4}$ in an anaerobic chamber (JACOMEX; $\mathrm{N}_{2}$-glovebox; $\left.\mathrm{O}_{2}(\mathrm{~g})<10 \mathrm{ppm}\right)$ at room temperature. Then, this solution was introduced into an $\mathrm{N}_{2}$-sparged $25 \% \mathrm{w} / \mathrm{v}$ ammonium hydroxide $\left(\mathrm{NH}_{4} \mathrm{OH}\right)$ solution, with continuous stirring at $1,400 \mathrm{rpm}$, leading to instantaneous precipitation of titanomagnetite nanoparticles. The solids were washed three times with ultra-pure water purged with $\mathrm{N}_{2}$ for $4 \mathrm{~h}$, and then centrifuged for $5 \mathrm{~min}$ at $4,000 \mathrm{rpm}$. The natural $\mathrm{pH}$ of the suspension was $8<\mathrm{pH}<8.5$. The materials $\mathrm{M}$, TM0.25 and TM0.75 were stored in the form of suspensions in de-oxygenated water under inert atmosphere, to limit the oxidation of the solid surface by dissolved oxygen, which could alter the reactivity toward the Fenton process.

\subsection{Characterization of the investigated particles}

To determine accurately the Fe(II)/Fe(III) ratio in both magnetite and titanomagnetites, an aliquot of each suspension was digested in $\mathrm{N}_{2}$-sparged $5 \mathrm{M} \mathrm{HCl}$ inside the glovebox overnight. The dissolved Fe(II) and Fe(III) concentrations were then measured with a modified phenanthroline method based on the addition (or lack of addition) of reducing agents to transform $\mathrm{Fe}(\mathrm{III})$ into $\mathrm{Fe}(\mathrm{II})$. By so doing, $\mathrm{Fe}(\mathrm{II})$ was determined directly without reducing agents, $\mathrm{Fe}_{\text {tot }}$ was determined in further runs upon addition of reducing agents, and Fe(III) was quantified as $\mathrm{Fe}_{\text {tot }}-\mathrm{Fe}$ (II) [34]. The B.E.T. surface area determined by multipoint $\mathrm{N}_{2}$ adsorption isotherm, using a Coulter (SA 3100) surface area analyzer, is given for each solid in Table 1.

Powder X-ray diffraction analysis (XRD; Bruker D8 Advance diffractometer, monochromatized $\mathrm{Cu}$ Ka1 radiation, $\lambda=1.5406 \AA$ ) was carried out on dried samples covered with a drop of glycerol, to avoid air oxidation during the XRD run. The XRD patterns of magnetite and of titanomagnetites are reported in Fig. 1(a), indexed with the peaks of magnetite.

Table 1

Acronyms, formulas of materials (the general formula is $\mathrm{Fe}_{3-\mathrm{x}} \mathrm{Ti}_{\mathrm{x}} \mathrm{O}_{4}$, with the relevant $x$ values also reported), $\mathrm{Fe}(\mathrm{II}) / \mathrm{Fe}(\mathrm{III})$ ratios and $\mathrm{BET}$ area

\begin{tabular}{llllc}
\hline Acronym & $x$ & Formula & $\mathrm{Fe}(\mathrm{II}) / \mathrm{Fe}(\mathrm{III})$ & $\begin{array}{l}\text { BET surface } \\
\text { area }\left(\mathrm{m}^{2} \mathrm{~g}^{-1}\right)\end{array}$ \\
\hline $\mathrm{M}$ & 0 & $\mathrm{Fe}_{3} \mathrm{O}_{4}$ & 0.41 & 95 \\
$\mathrm{TM} 0.25$ & 0.25 & $\mathrm{Fe}_{2.75} \mathrm{Ti}_{0.25} \mathrm{O}_{4}$ & 0.80 & 118 \\
$\mathrm{TM} 0.75$ & 0.75 & $\mathrm{Fe}_{2.25} \mathrm{Ti}_{0.75} \mathrm{O}_{4}$ & 3.26 & 132 \\
\hline
\end{tabular}

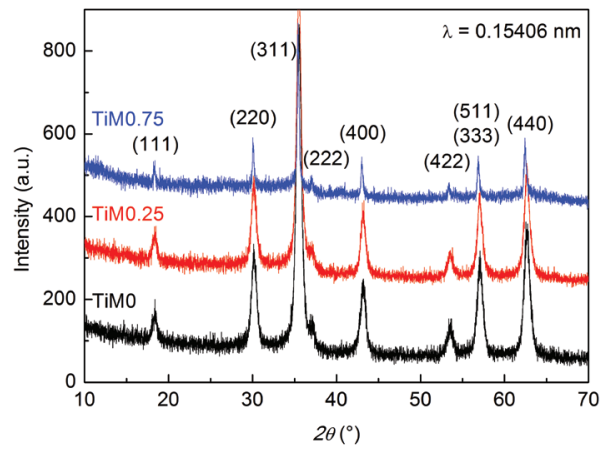

M

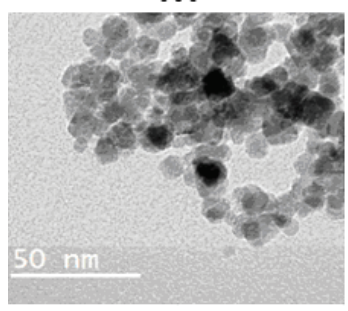

TM0.25

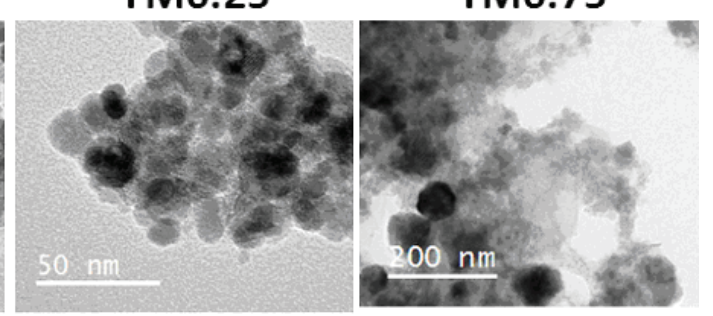

(b)

Fig. 1. (a) Powder XRD patterns for the synthesized materials. The Miller indices of the characteristic peaks of magnetite are indicated. (b) TEM images for the synthesized magnetite (M) and the two titanomagnetites TM0.25 and TM0.75. 
Transmission electron microscopy images (Fig. 1(b)) revealed particle aggregates of around $15 \mathrm{~nm}$ diameter for $\mathrm{M}$ and TM0.25, but larger particles (up to $\sim 50 \mathrm{~nm}$ diameter) in the case of TM0.75. Non-structural Ti(IV)/Fe(II) amorphous phase on the $x=0.75$ nanoparticle surface could also be seen. This finding is in agreement with a previous study [33], where $\mathrm{Ti}$ was expected to be incorporated in magnetite only up to $x=0.38$. The inhomogeneous distribution of particles, and the presence of a non-structural Ti(IV)/Fe(II) amorphous phase for $x=0.75$, may explain why TM0.75 had larger particle diameter as well as larger surface area, compared with $\mathrm{M}$ and TM0.25.

\subsection{Phenol degradation experiments}

Phenol degradation experiments were carried out in $50 \mathrm{~mL}$ beakers containing a suspension of the heterogeneous catalyst (M, TM0.25 or TM0.75), $\mathrm{H}_{2} \mathrm{O}_{2}$, and other reagents when needed. Unless otherwise specified and whenever applicable, the concentration values in the reaction mixture were as follows: $0.1 \mathrm{~g} \mathrm{~L}^{-1}$ for $\mathrm{M} / \mathrm{TM} 0.25$ / TM0.75, $1.0 \times 10^{-4} \mathrm{M}$ for phenol, $1.0 \times 10^{-3} \mathrm{M}$ for $\mathrm{H}_{2} \mathrm{O}_{2}$. The volume of the reaction mixture was $30 \mathrm{~mL}$. The experiments were carried out in aerated solution under magnetic stirring, correcting the $\mathrm{pH}$ values upon addition of $\mathrm{HClO}_{4}$ or $\mathrm{NaOH}$. The choice of $\mathrm{HClO}_{4}$ was justified by the fact that the perchlorate anion does not react significantly with ${ }^{\circ} \mathrm{OH}[14]$. In all the cases, the course of the reaction was monitored by withdrawing $2 \mathrm{~mL}$ sample aliquots from the reaction mixture at predetermined time intervals.

To stop the Fenton reaction in the withdrawn aliquots, the solid catalyst was removed by filtration using Millipore Millex HV filters ( $0.45 \mu \mathrm{m}$ pore diameter), and the filtered solution was then diluted with 1:1 methanol to quench the reactive species that could still be generated by dissolved $\mathrm{Fe}$ and $\mathrm{H}_{2} \mathrm{O}_{2}[28,35]$.

Phenol was quantified by liquid chromatography, using a HPLC-DAD VWR-Hitachi Elite LaChrom instrument equipped with L2455 diode array detector, L2130 quaternary pump module, L2300 column oven (set at $40^{\circ} \mathrm{C}$ ), L2200 autosampler (sample injection volume $60 \mu \mathrm{L}$ ), Duratec vacuum degasser and a reverse-phase column Merck LiChroCART, packed with LiChrospher 100 RP18 (125 mm × $4 \mathrm{~mm} \times 5 \mu \mathrm{m}$ ). The samples were eluted with a 60:40 mixture of an aqueous solution of $\mathrm{H}_{3} \mathrm{PO}_{4}(\mathrm{pH} 2.8)$ and methanol, at $1.0 \mathrm{~mL} \mathrm{~min}{ }^{-1}$ flow rate. In these conditions the retention time of phenol was $3.8 \mathrm{~min}$, and the column dead time was $1.2 \mathrm{~min}$. The detection wavelength was set at $268 \mathrm{~nm}$.

Homogeneous Fenton experiments were also carried out to assess the role in phenol degradation of dissolved Fe (leached from the heterogeneous catalysts and monitored over time, vide infra for dissolved $\mathrm{Fe}$ monitoring), using soluble iron salts $\left(\mathrm{FeSO}_{4} \times 7 \mathrm{H}_{2} \mathrm{O}\right.$ and $\left.\mathrm{Fe}\left(\mathrm{NO}_{3}\right)_{3} \times 9 \mathrm{H}_{2} \mathrm{O}\right)$. The concentration of the added iron salts was chosen to be representative of the maximum levels of leached iron from $\mathrm{M}$, TM0.25 and TM0.75, determined as described in the following section.

\subsection{Monitoring of dissolved $\mathrm{Fe}(\mathrm{II}), \mathrm{Fe}(\mathrm{III})$ and $\mathrm{H}_{2} \mathrm{O}_{2}$}

The determination of dissolved (leached) iron [36] in the presence of M, TM0.25 and TM0.75, and of the amount of residual $\mathrm{H}_{2} \mathrm{O}_{2}$ in solution was carried out with colorimetric procedures. In these experiments methanol was not used as quencher to avoid analytical biases, and the analytical determinations were done soon after sample-aliquot withdrawal [28]. The registration of the UV-Vis spectra was carried out with a Varian Cary 100 Scan double-beam UV-Vis spectrophotometer, using Hellma quarz cuvettes with $1 \mathrm{~cm}$ optical path length. The monitoring of dissolved iron was aimed at the determination of the time trends of $\mathrm{Fe}(\mathrm{II})$ and $\mathrm{Fe}$ (III) leached from the particles, which may also be converted into one another by homogeneous-phase Fenton reactions. At scheduled reaction times, 7-mL sample aliquots were withdrawn from the reaction mixture that initially contained TM0.75, TM0.25 or M $\left(0.1 \mathrm{~g} \mathrm{~L}^{-1}\right.$ loading $)$, phenol $\left(1.0 \times 10^{-4} \mathrm{M}\right)$, $\mathrm{H}_{2} \mathrm{O}_{2}\left(1.0 \times 10^{-3} \mathrm{M}\right)$, and $\mathrm{HClO}_{4}$ for $\mathrm{pH}$ correction. The samples were filtered as mentioned above to remove the suspended particles.

For Fe(II) determination, a $5 \mathrm{~mL}$ aliquot of the filtered solution was introduced into a $10 \mathrm{~mL}$ flask that also contained $1.82 \mathrm{~mL}$ of $0.011 \mathrm{M} \mathrm{1,10-phenanthroline} \mathrm{(phen)} \mathrm{in}$ water, $\mathrm{H}_{2} \mathrm{SO}_{4}$ to reach $\mathrm{pH} 2$, and water to volume. To ensure a complete reaction between $\mathrm{Fe}(\mathrm{II})$ and the phen complexing agent, with formation of a complex called ferroin $\left(\left[\mathrm{Fe}(\mathrm{phen})_{3}\right]^{2+}[34,37]\right)$, the colored solutions were analyzed after $5 \mathrm{~min}$ from preparation. Ferroin has an absorption maximum at $510 \mathrm{~nm}$, and the intensity of the color of the red-orange solution depends on the Fe(II) concentration. With this method, the Fe(II) limit of quantification (LoQ) was $(5.3 \pm 0.8) \times 10^{-8} \mathrm{M}$.

$\mathrm{Fe}(\mathrm{III})$ was quantified using the reaction with the thiocyanate ion $\left(\mathrm{SCN}^{-}\right)$that develops a red color in the presence of $\mathrm{Fe}(\mathrm{III})$, possibly because of the formation of the complex $\left[\mathrm{Fe}(\mathrm{SCN})_{6}\right]^{3-}[36,38]$. In a $10 \mathrm{~mL}$ flask it was introduced a $5 \mathrm{~mL}$ aliquot of the filtered solution, $1 \mathrm{~mL}$ of aqueous KSCN $\left(5.14 \times 10^{-3} \mathrm{M}\right), \mathrm{H}_{2} \mathrm{SO}_{4}$ to $\mathrm{pH} 2$ and water to volume. After $5 \mathrm{~min}$ the solution was spectrophotometrically analyzed at $457 \mathrm{~nm}$, and with this method the LOQ of Fe(III) was $(8.0 \pm 2.6) \times 10^{-6} \mathrm{M}$.

The determination of $\mathrm{H}_{2} \mathrm{O}_{2}$ used the peroxidaseampyrone method [28]. The color-forming reagent contained $0.10 \mathrm{~g}$ of ampyrone, $0.234 \mathrm{~g}$ of phenol, $0.2201 \mathrm{~g}$ of $\mathrm{Na}_{2} \mathrm{HPO}_{4^{\prime}} 0.7112 \mathrm{~g}$ of $\mathrm{NaH}_{2} \mathrm{PO}_{4^{\prime}}$ and few crystals of horseradish peroxidase in $100 \mathrm{~mL}$ of ultra-pure water. In the presence of phenol, of $\mathrm{H}_{2} \mathrm{O}_{2}$ and of the enzyme, there is formation of a colored adduct (quinoneimine dye) between oxidized phenol and ampyrone, which can be detected at $505 \mathrm{~nm}$ [39]. Operationally, in a 10-mL flask it was introduced $2 \mathrm{~mL}$ of color-forming reagent, 1-5 mL of filtered solution, as well as water to volume. The volume of the filtered sample was chosen in order to carry out the spectrophotometric measure within the linearity range of the method $\left(2.0 \times 10^{-6}-2.0 \times 10^{-4} \mathrm{M} \mathrm{H}_{2} \mathrm{O}_{2}\right.$ in the flask, corresponding to 0.01-1.12 absorbance units at $505 \mathrm{~nm}$ ) [28]. The LoQ of $\mathrm{H}_{2} \mathrm{O}_{2}$ with this method was $(2.0 \pm 0.6) \times 10^{-8} \mathrm{M}$.

\subsection{Error bars on the plots}

The error bars to the concentration values of phenol, $\mathrm{Fe}(\mathrm{II}), \mathrm{Fe}(\mathrm{III})$ and $\mathrm{H}_{2} \mathrm{O}_{2}$ reported on the plots represent the standard errors of experimental replicas. 


\section{Results and discussion}

\subsection{Effect of $\mathrm{pH}$}

The optimum $\mathrm{pH}$ value is often around 3 for the homogeneous Fenton reaction. Fe(III) shows maximum solubility in acidic solutions and at $\mathrm{pH} 3$ it mainly occurs in the form of $\mathrm{FeOH}^{2+}$, which undergoes relatively fast reduction to $\mathrm{Fe}(\mathrm{II})$ [14]. Furthermore, an acidic environment is able to maximize the ${ }^{\circ} \mathrm{OH}$ production at the expense of other less reactive species, such as the ferryl ion $\mathrm{FeO}^{2+}[18]$. Heterogeneous Fenton reactions often operate in a wider $\mathrm{pH}$ range than homogeneous Fenton $[15,28]$. Although, the decomposition rate of organic contaminants in heterogeneous systems is often slower than in the classic homogeneous Fenton reaction [40], in this work kinetic experiments were run over a time scale of only $60 \mathrm{~min}$, because a reaction time of 20-30 min was usually long enough to achieve complete phenol degradation. Moreover, higher reaction times would be hardly applicable in real treatment plants.

Fig. 2 shows the time trend of phenol in the $\mathrm{pH}$ range of 2-6, in the presence of TM0.75 (Fig. 2(a)), TM0.25 (Fig. 2(b)), or M (Fig. 2(c)). As expected, the optimum $\mathrm{pH}$ value for phenol degradation was 3 and, in these conditions, complete degradation was achieved within one hour or even less. At pH 2 and 4 the process was significantly slower and it did not lead to complete phenol degradation, while at $\mathrm{pH} \geq 5$ it became ineffective. It is interesting to observe that the three materials showed comparable reactivity at $\mathrm{pH} 3$. Here, relatively fast phenol degradation could be achieved with a relatively low loading of the solid Fe-containing material, and with an $\mathrm{H}_{2} \mathrm{O}_{2}$ /substrate ratio of 10:1. These conditions appear as reasonably promising [10] for the Fenton reactivity of the investigated materials. Moreover, control experiments carried out in the absence of $\mathrm{H}_{2} \mathrm{O}_{2}$ allowed us to exclude a significant adsorption of phenol on the suspended solids.

Unfortunately, operating at $\mathrm{pH} 3$ could be problematic in the context of wastewater treatment because of the possible need to first acidify wastewater and then correct the $\mathrm{pH}$ back to neutrality. In addition to the significant costs of the pH-fixing reagents [41], wastewater salinity would be enhanced by the acidification/neutralization steps [14]. At acidic $\mathrm{pH}$ one might also have significant iron leaching from the particles [28], and the precipitation of dissolved iron upon neutralization would require a further sedimentation step. To avoid these drawbacks, it is convenient to extend the operational $\mathrm{pH}$ to higher values.

The results shown in Fig. 2 suggest that only TM0.75 and $\mathrm{M}$ induced significant (albeit not complete) phenol degradation at $\mathrm{pH} 4$, while TM0.25 was not reactive at all at that $\mathrm{pH}$ value. An optimization of the reaction conditions at $\mathrm{pH} 4$ was then carried out, to see if and to what extent the studied materials are able to achieve effective degradation of the substrate.

\subsection{Effect of phenol and $\mathrm{H}_{2} \mathrm{O}_{2}$ concentration at $\mathrm{pH} 4$}

In the previous section it was shown that incomplete degradation of $0.1 \mathrm{mM}$ phenol was obtained at $\mathrm{pH} 4$. Operation with $10^{-4} \mathrm{M}$ phenol is experimentally convenient and provides quick and easy insight into the reactivity of the studied materials. However, it is seldom representative of
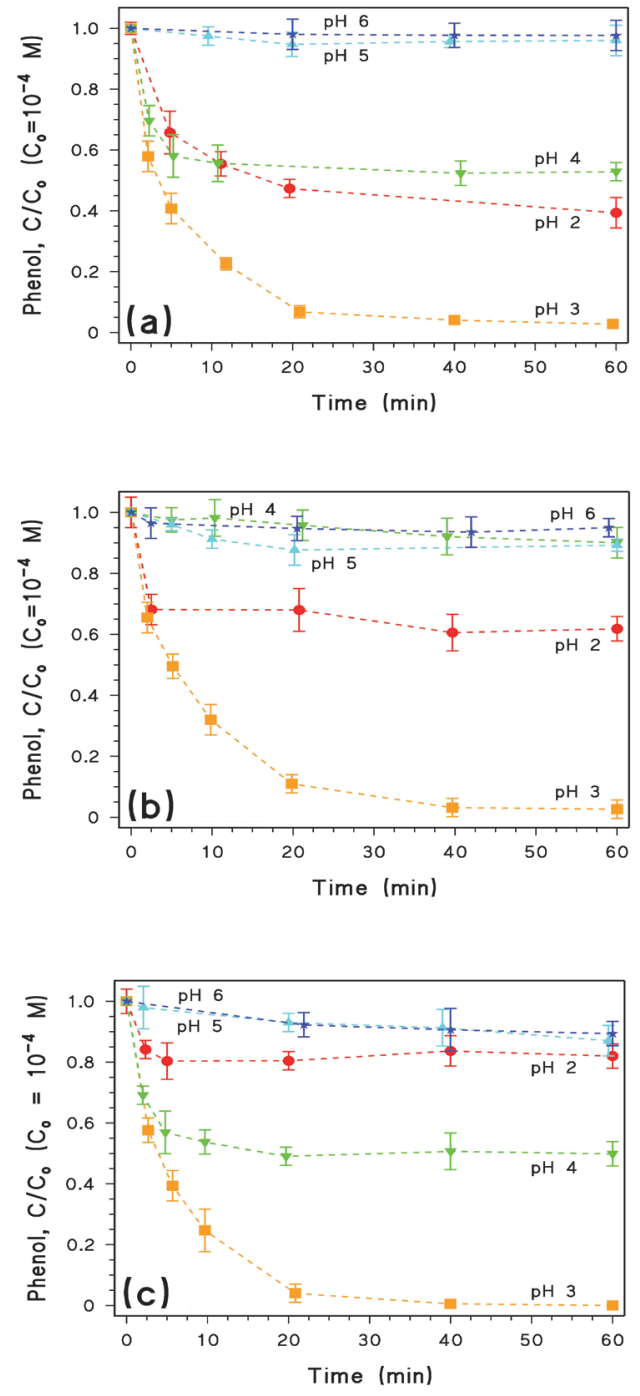

Fig. 2. Time trends of phenol (initial concentration $1.0 \times 10^{-4} \mathrm{M}$ ) in the presence of $\mathrm{H}_{2} \mathrm{O}_{2}\left(1.0 \times 10^{-3} \mathrm{M}\right)$ and: (a) TM0.75, (b) TM0.25, or (c) $\mathrm{M}$ (all at $0.1 \mathrm{~g} \mathrm{~L}^{-1}$ loading), at different $\mathrm{pH}$ values.

the conditions occurring in technological systems for water treatment, where the pollutant concentrations are usually much lower. Furthermore, one might imagine that the incomplete phenol removal observed in the case of $\mathrm{M}$ and TM 0.75 could be caused by an excess of the substrate (phenol) over the Fenton reactants, and that complete removal may be obtained when starting from a lower phenol concentration value. Therefore, in further experiments the solid catalyst loading $\left(0.1 \mathrm{~g} \mathrm{~L}^{-1}\right)$ and the $\mathrm{H}_{2} \mathrm{O}_{2}$ concentration $\left(10^{-3} \mathrm{M}\right)$ were kept at the usual levels, but the initial concentration of phenol was lowered. The relevant results are reported in Fig. 3. These results further suggest that TM0.25 was inactive at $\mathrm{pH} 4$ (Fig. 3(b)), but TM0.75 was also unable to induce significant degradation of phenol at an initial concentration of the latter below $10^{-4} \mathrm{M}$ (Fig. 3(a)). Actually, a low substrate concentration improves the stoichiometric oxidant/substrate ratio, but it can also slow down the reaction kinetics [14]. Furthermore, a more elevated $\left[\mathrm{H}_{2} \mathrm{O}_{2}\right][\text { Phenol }]^{-1}$ ratio would 

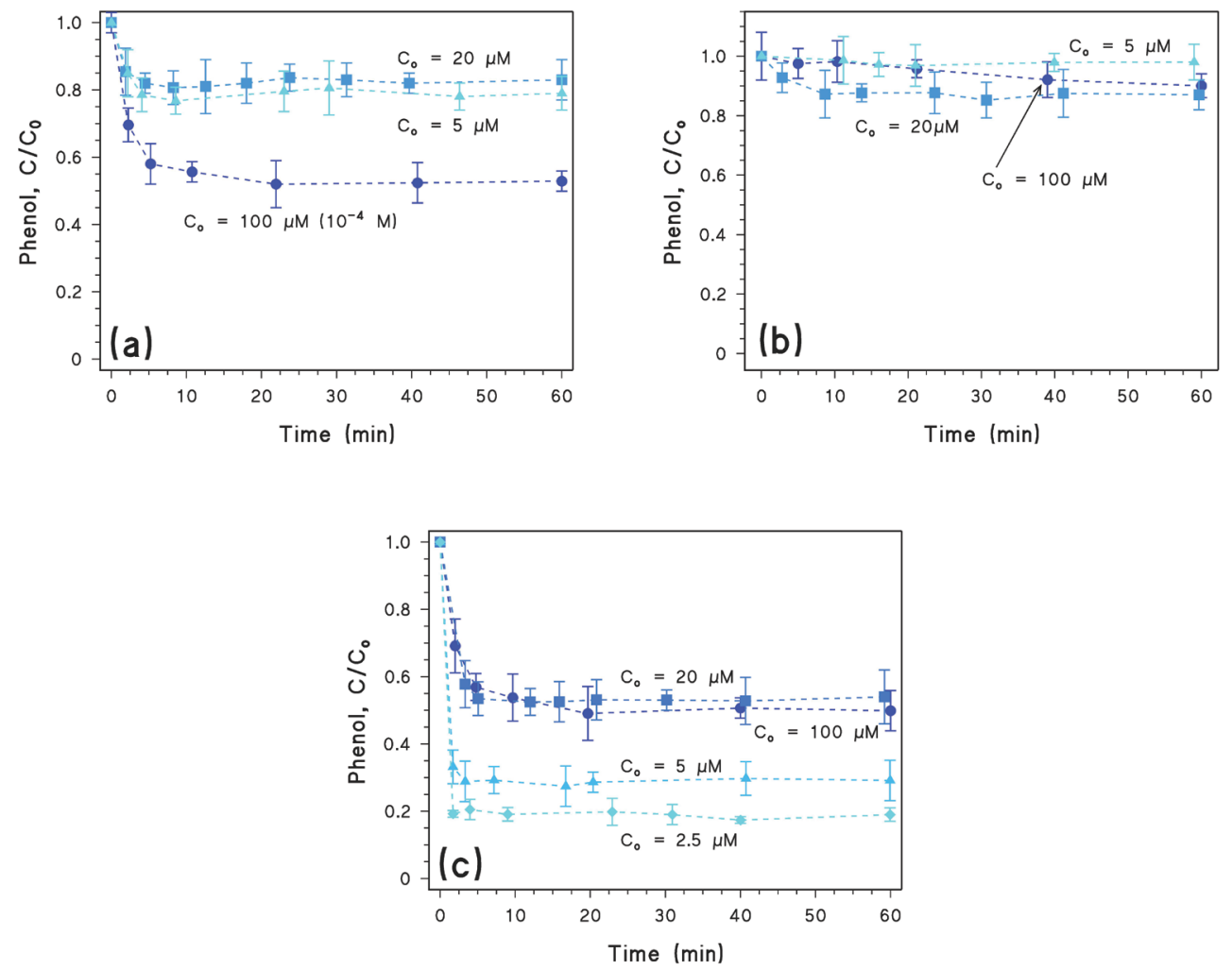

Fig. 3. Time trends of phenol at different initial concentration values $(\mathrm{Co})$ in the presence of $\mathrm{H}_{2} \mathrm{O}_{2}\left(1.0 \times 10^{-3} \mathrm{M}\right)$ and (a) TM0.75, (b) TM0.25, or (c) M (all $0.1 \mathrm{~g} \mathrm{~L}^{-1}$ ), at $\mathrm{pH} 4$.

also shift in favor of $\mathrm{H}_{2} \mathrm{O}_{2}$ the competition between $\mathrm{H}_{2} \mathrm{O}_{2}$ and phenol for reaction with $\mathrm{OH}$ [14], thereby inhibiting phenol degradation. In contrast, the degradation of phenol in the presence of $\mathrm{M}$ improved as the phenol concentration was decreased (Fig. 3(c)). Because in the case of $\mathrm{M}$ there might be as well an unfavorable effect of an elevated $\left[\mathrm{H}_{2} \mathrm{O}_{2}\right][\text { Phenol }]^{-1}$ ratio, additional experiments were carried out by lowering the initial $\left[\mathrm{H}_{2} \mathrm{O}_{2}\right]$ value (see Fig. 4). The degradation of phenol by $\mathrm{M}$ improved at lower $\mathrm{H}_{2} \mathrm{O}_{2}$ (comparable experiments with TM0.75 and TM0.25 did not improve degradation, however, data not shown), and practically complete removal of $2.5 \mu \mathrm{M}$ phenol could be achieved in 40 min with $50 \mu \mathrm{M} \mathrm{H}_{2} \mathrm{O}_{2}$ and $0.1 \mathrm{~g} \mathrm{~L}^{-1} \mathrm{M}$ at $\mathrm{pH}$ 4. These results suggest that, in the case of $\mathrm{M}$, the Fenton reactivity may be extended up to $\mathrm{pH}$ 4. The latter conditions could entail a considerable saving of $\mathrm{pH}$-fixing reagents over operation at $\mathrm{pH} 3$.

\subsection{Time trends of $\mathrm{H}_{2} \mathrm{O}_{2}$ and of dissolved $\mathrm{Fe}$ (II) and $\mathrm{Fe}$ (III)}

The rationale behind the spectrophotometric monitoring of $\mathrm{H}_{2} \mathrm{O}_{2}, \mathrm{Fe}(\mathrm{II})$ and $\mathrm{Fe}(\mathrm{III})$ in solution is manifold. The first reason is that the Fenton reaction may be triggered by $\mathrm{H}_{2} \mathrm{O}_{2}$ and by the iron species located at the solid surface (it is the case of metallic Fe [28]) or, as an alternative, by the partial dissolution of the Fe-containing mineral to yield dissolved $\mathrm{Fe}(\mathrm{II}) / \mathrm{Fe}(\mathrm{III})$ that then react with $\mathrm{H}_{2} \mathrm{O}_{2}$ [30]. Obviously, the importance of the reaction pathway involving the dissolved species increases as the concentration of such species in solution is higher. Another reason for monitoring dissolved Fe(II)

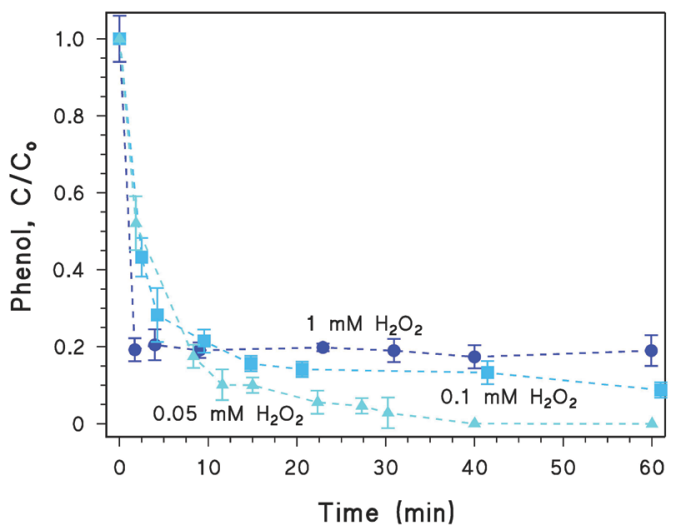

Fig. 4. Time trends of phenol (initial concentration $2.5 \times 10^{-6} \mathrm{M}$ ) in the presence of $\mathrm{M}\left(0.1 \mathrm{~g} \mathrm{~L}^{-1}\right)$ and different initial concentrations of $\mathrm{H}_{2} \mathrm{O}_{2}$ at $\mathrm{pH} 4$.

and $\mathrm{Fe}(\mathrm{III})$ is linked to the Fe leaching from the solid catalyst. Actually, total dissolved Fe at the end of the treatment may exceed the limits for wastewater discharge (in several countries there is a total dissolved Fe limit in wastewater of $1 \mathrm{mg} \mathrm{L}^{-1}$, which corresponds to $\sim 2 \times 10^{-5} \mathrm{M}$ [28]), in which case a further Fe precipitation step should be added (however, $\mathrm{Fe}(\mathrm{III})$ precipitation would take place anyway after neutralization, which is needed if the reaction is carried out under acidic conditions). An additional issue is that the occurrence 
of $\mathrm{H}_{2} \mathrm{O}_{2}$ can influence the speciation of dissolved $\mathrm{Fe}$, because $\mathrm{H}_{2} \mathrm{O}_{2}$ is mainly involved in the oxidation of $\mathrm{Fe}(\mathrm{II})$ to $\mathrm{Fe}(\mathrm{III})$ [25]. Finally, the toxicity of $\mathrm{H}_{2} \mathrm{O}_{2}$ for bacteria may pose problems if the Fenton reaction is to be followed by a biological treatment step, but $\mathrm{H}_{2} \mathrm{O}_{2}$ could even be useful for disinfection purposes if, on the contrary, the Fenton process takes place soon before wastewater discharge [42].

The time trends of $\mathrm{Fe}(\mathrm{II}), \mathrm{Fe}(\mathrm{III})$ and $\mathrm{H}_{2} \mathrm{O}_{2}$ in the presence of TM0.75, TM0.25 and M are reported in Figs. 5-7, respectively. In particular, the trends were monitored at $\mathrm{pH} 3$ (results reported in Figs. 5(a), 6(a), 7(a)) and at pH 4 (results in Figs. 5(b), 6(b), 7(b)). As expected, the concentration values of $\mathrm{Fe}(\mathrm{II}, \mathrm{III})$ were higher at $\mathrm{pH} 3$, where the iron species are more soluble than at $\mathrm{pH} 4$ [43]. Note that the stock catalysts (M, TM0.25 and TM0.75) were stored as aqueous suspensions (without $\mathrm{pH}$-modifying reagents) under inert $\mathrm{N}_{2}$ atmosphere: Fe species had thus time to leach from the solid, and it is thus not surprising to find dissolved iron at the beginning of the reaction.

At $\mathrm{pH} 3$, where all the three materials behaved similarly toward phenol degradation, the concentration values of dissolved $\mathrm{Fe}(\mathrm{II}, \mathrm{III})$ were also similar in the different cases. In contrast, at $\mathrm{pH} 4$ the dissolved Fe concentration followed the order TM0.75 > M >> TM0.25. Interestingly, TM0.25 was
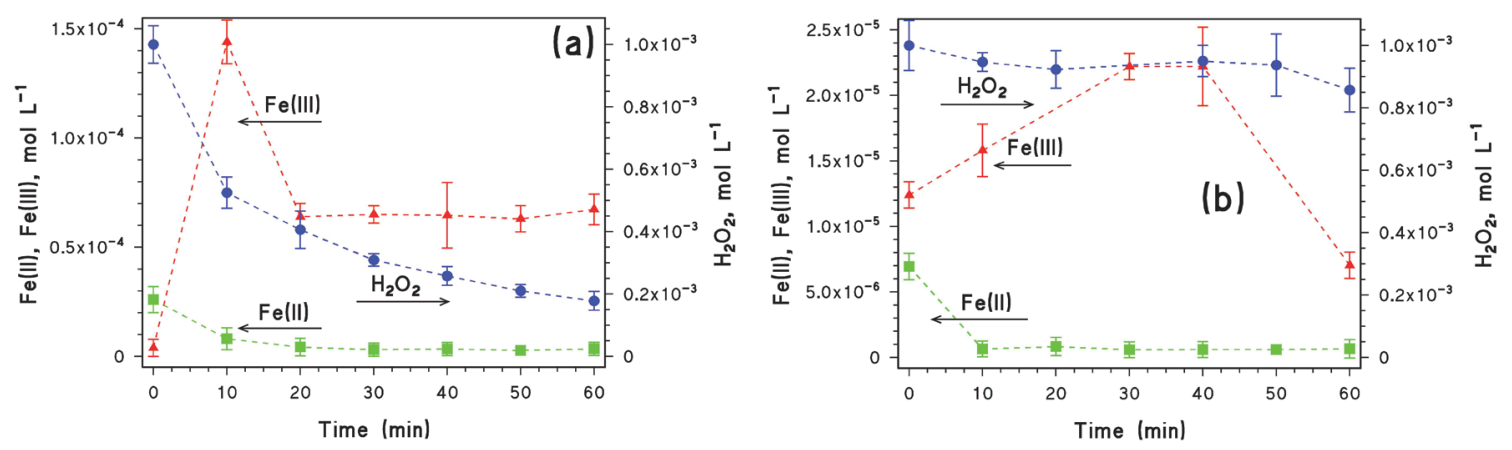

Fig. 5. Time trends of $\mathrm{H}_{2} \mathrm{O}_{2}$ (right y-axis, initial concentration $1.0 \times 10^{-3} \mathrm{M}$ ) and of dissolved $\mathrm{Fe}(\mathrm{II})$ and $\mathrm{Fe}(\mathrm{III})$ (left y-axis) upon degradation of phenol $\left(1.0 \times 10^{-4} \mathrm{M}\right)$ in the presence of TM0.75 $\left(0.1 \mathrm{~g} \mathrm{~L}^{-1}\right)$ and $\mathrm{H}_{2} \mathrm{O}_{2^{\prime}}$ at (a) $\mathrm{pH} 3$ and (b) $\mathrm{pH} 4$.
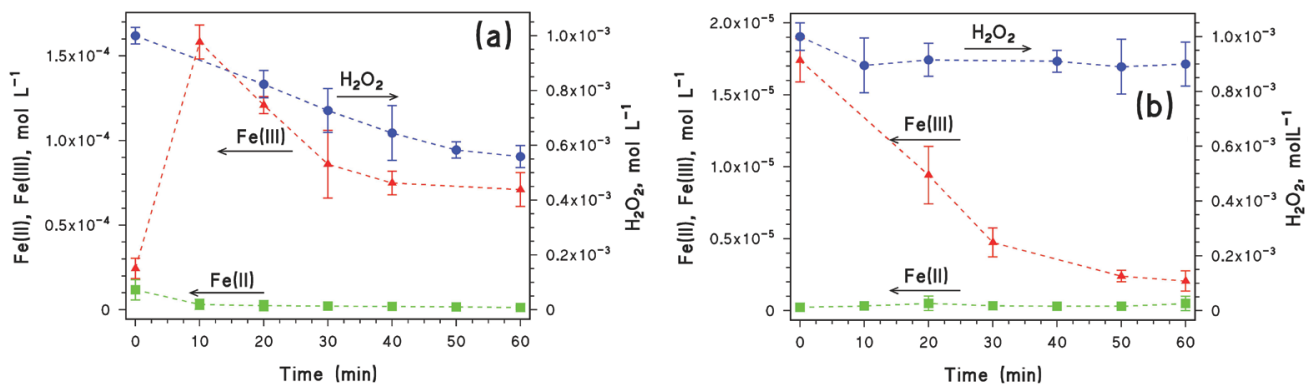

Fig. 6. Time trends of $\mathrm{H}_{2} \mathrm{O}_{2}$ (right y-axis, initial concentration $1.0 \times 10^{-3} \mathrm{M}$ ) and of dissolved $\mathrm{Fe}(\mathrm{II})$ and $\mathrm{Fe}(\mathrm{III})$ (left y-axis) upon degradation of phenol $\left(1.0 \times 10^{-4} \mathrm{M}\right)$ in the presence of TM0.25 $\left(0.1 \mathrm{~g} \mathrm{~L}^{-1}\right)$ and $\mathrm{H}_{2} \mathrm{O}_{2}$, at (a) $\mathrm{pH} 3$ and (b) $\mathrm{pH} 4$.
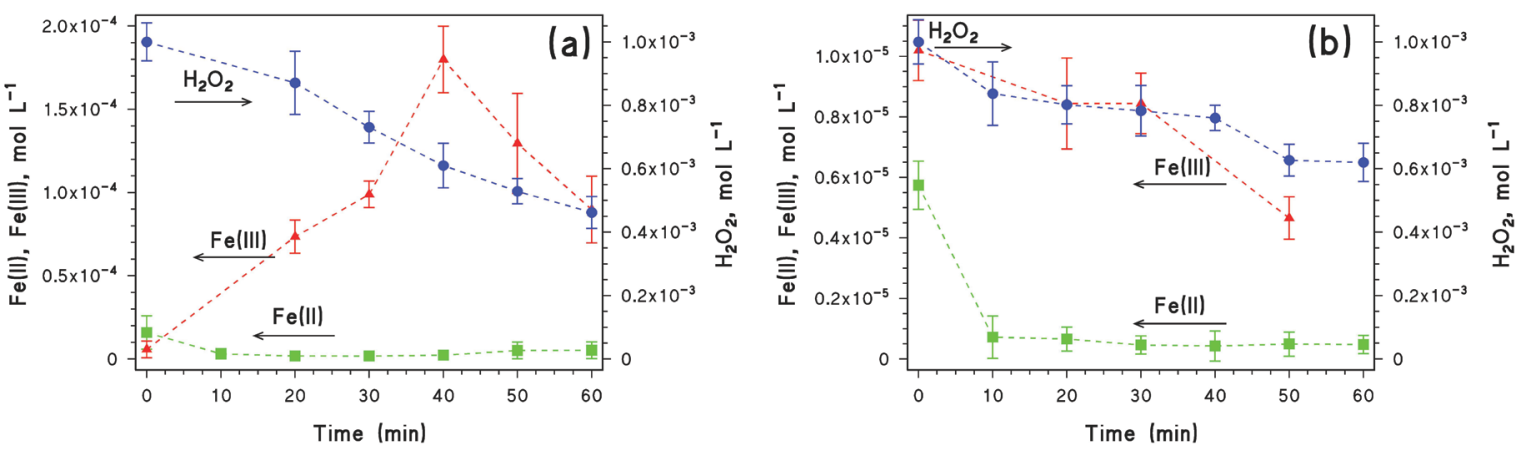

Fig. 7. Time trends of $\mathrm{H}_{2} \mathrm{O}_{2}$ (right y-axis, initial concentration $1.0 \times 10^{-3} \mathrm{M}$ ) and of dissolved $\mathrm{Fe}(\mathrm{II})$ and $\mathrm{Fe}(\mathrm{III})$ (left y-axis) upon degradation of phenol $\left(1.0 \times 10^{-4} \mathrm{M}\right)$ in the presence of $\mathrm{M}\left(0.1 \mathrm{~g} \mathrm{~L}^{-1}\right)$ and $\mathrm{H}_{2} \mathrm{O}_{2^{\prime}}$ at (a) $\mathrm{pH} 3$ and (b) $\mathrm{pH} 4$. 
inactive at $\mathrm{pH} 4$ and it leached no Fe: this finding suggests that the Fenton process might involve at least in part the dissolved Fe species. Total dissolved $\mathrm{Fe}(\mathrm{Fe}(\mathrm{II})+\mathrm{Fe}(\mathrm{III}))$ at the end of the reaction was above the $1 \mathrm{mg} \mathrm{L}^{-1}\left(2 \times 10^{-5} \mathrm{M}\right)$ limit at $\mathrm{pH}$ 3 but not at $\mathrm{pH} 4$, at least after $1 \mathrm{~h}$ reaction time. Operation at the higher $\mathrm{pH}$ value would avoid issues related to Fe concentration in discharged wastewater, but Fe precipitation could still occur upon treated-wastewater neutralization.

The time trends at $\mathrm{pH} 3$ showed an initial Fe(III) increase, and a decrease in both $\mathrm{Fe}(\mathrm{II})$ and $\mathrm{H}_{2} \mathrm{O}_{2}$, which is fully consistent with the reaction (1) between $\mathrm{Fe}(\mathrm{II})$ and $\mathrm{H}_{2} \mathrm{O}_{2}$ to produce the Fenton reactive species. The decrease of Fe(III) after the concentration maximum is probably caused by the incorporation of this species into the surface layer of the suspended solid [12]. In the case of TM0.25 at $\mathrm{pH} 4$, the lack of $\mathrm{H}_{2} \mathrm{O}_{2}$ decay and the very low $\mathrm{Fe}(\mathrm{II})$ leaching are consistent with the absence of reactivity toward phenol, while both $\mathrm{H}_{2} \mathrm{O}_{2}$ and $\mathrm{Fe}(\mathrm{II})$ decay were observed in the most reactive system (M). A decrease in Fe(III) concentration, continuous (M, TM0.25) or only at long reaction times (TM0.75) could be observed at $\mathrm{pH} 4$ as well. This finding is again consistent with an ability of the suspended solids to capture dissolved Fe(III) species.

\subsection{Homogeneous Fenton processes}

As suggested earlier, the leaching of iron from the surface of the catalysts can trigger the homogeneous Fenton reaction in solution. To assess whether the homogeneous processes are important in the presence of $\mathrm{M}, \mathrm{TM} 0.25$ and TM0.75, control experiments were carried out in the homogeneous phase by using dissolved $\mathrm{FeSO}_{4}$ and $\mathrm{Fe}\left(\mathrm{NO}_{3}\right)_{3^{\prime}}$ in the presence of $\mathrm{H}_{2} \mathrm{O}_{2}$. The goal was to have initial concentration levels of dissolved $\mathrm{Fe}(\mathrm{II})$ or $\mathrm{Fe}(\mathrm{III})$ in the homogeneous-phase experiments, which were equal to the maximum values detected for the two dissolved species leached from each catalyst in the heterogeneous experiments at $\mathrm{pH} 3$ and 4 (see the relevant data in Figs. 5-7). The degradation of $10^{-4} \mathrm{M}$ phenol in the presence of $10^{-3} \mathrm{M} \mathrm{H}_{2} \mathrm{O}_{2}$, and of dissolved $\mathrm{Fe}(\mathrm{II})$ or $\mathrm{Fe}(\mathrm{III})$ concentrations as per the previous discussion is reported in Fig. 8, together with the phenol trends observed for the degradation in the presence of TM0.75 (8(a)), TM $0.25(8(\mathrm{~b}))$ and $\mathrm{M}(8(\mathrm{c}))$, at both $\mathrm{pH} 3$ and 4 . The results derived from the comparison suggest for instance that phenol degradation by TM0.75 at $\mathrm{pH} 3$ was largely due to homogeneous processes, which played important roles also in the other cases.
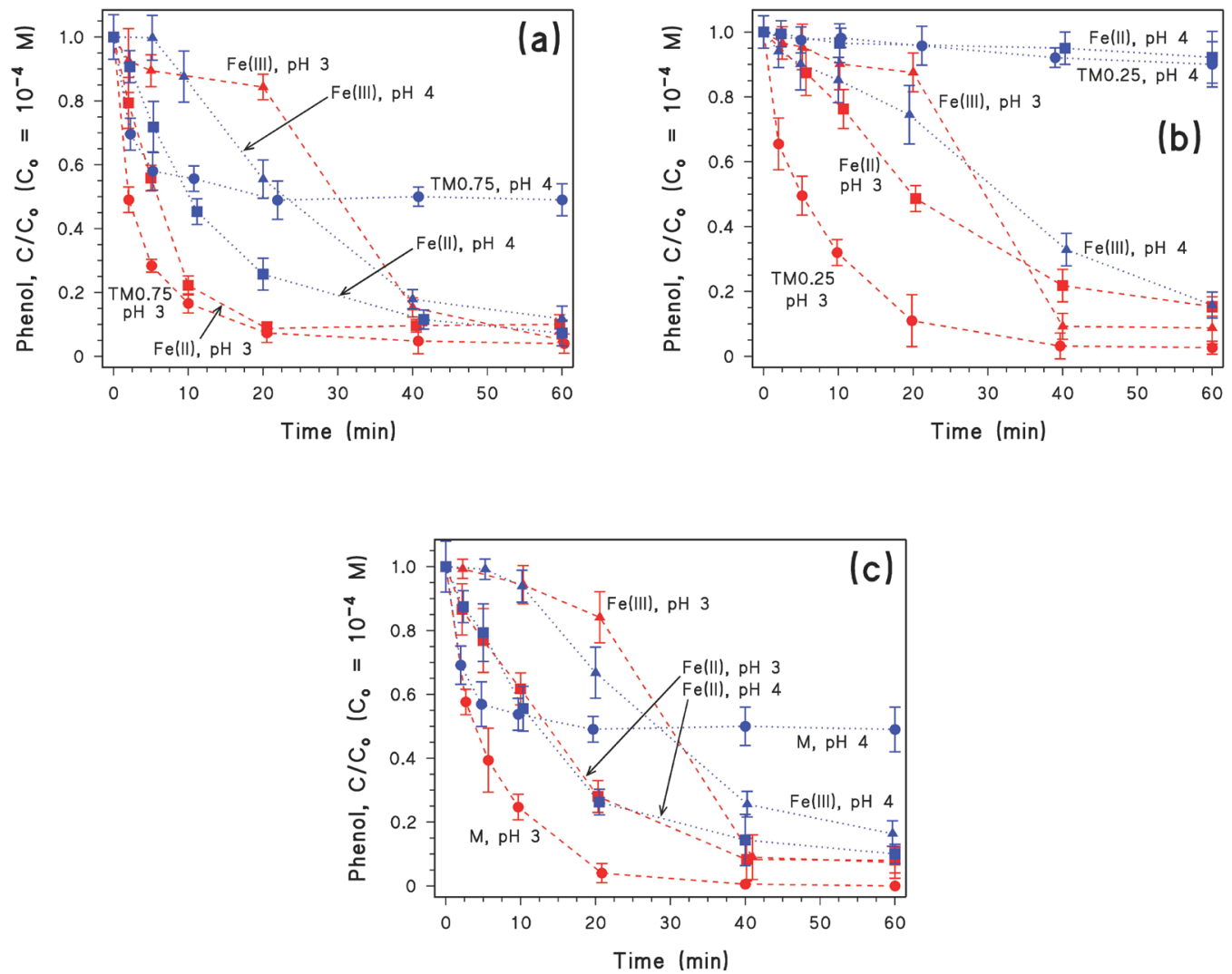

Fig. 8. Time trends of phenol $\left(1.0 \times 10^{-4} \mathrm{M}\right)$, (a) in the presence of TM0.75 $\left(0.1 \mathrm{~g} \mathrm{~L}^{-1}\right)$, or in the homogeneous phase with the maximum concentrations of $\mathrm{Fe}(\mathrm{II})\left(2.6 \times 10^{-5} \mathrm{M}\right.$ at pH $3,6.9 \times 10^{-6} \mathrm{M}$ at pH 4$)$ and $\mathrm{Fe}(\mathrm{III})\left(1.4 \times 10^{-4} \mathrm{M}\right.$ at pH $3,2.2 \times 10^{-5} \mathrm{M}$ at $\left.\mathrm{pH} 4\right)$ leached from $0.1 \mathrm{~g} \mathrm{~L}^{-1}$ TM0.75, at $\mathrm{pH} 3$ and 4 ; (b) In the presence of TM0.25 $\left(0.1 \mathrm{~g} \mathrm{~L}^{-1}\right)$, or in the homogeneous phase with the maximum concentrations of Fe(II) $\left(1.2 \times 10^{-5} \mathrm{M}\right.$ at $\mathrm{pH} 3,2 \times 10^{-7} \mathrm{M}$ at $\left.\mathrm{pH} 4\right)$ and $\mathrm{Fe}(\mathrm{III})\left(1.6 \times 10^{-4} \mathrm{M}\right.$ at $\mathrm{pH} 3,1.7 \times 10^{-5} \mathrm{M}$ at $\mathrm{pH}$ 4) leached from $0.1 \mathrm{~g} \mathrm{~L}^{-1} \mathrm{TM} 0.25$, at $\mathrm{pH} 3$ and 4 ; (c) In the presence of $\mathrm{M}\left(0.1 \mathrm{~g} \mathrm{~L}^{-1}\right)$, or in the homogeneous phase with the maximum concentrations of $\mathrm{Fe}(\mathrm{II})\left(1.8 \times 10^{-5} \mathrm{M}\right.$ at $\mathrm{pH} 3$, $5 \times 10^{-6} \mathrm{M}$ at $\left.\mathrm{pH} 4\right)$ and $\mathrm{Fe}(\mathrm{III})\left(1.8 \times 10^{-4} \mathrm{M}\right.$ at $\mathrm{pH} 3,1.0 \times 10^{-5} \mathrm{M}$ at $\left.\mathrm{pH} 4\right)$ leached from $0.1 \mathrm{~g} \mathrm{~L}^{-1} \mathrm{M}$, at $\mathrm{pH} 3$ and 4 . The data points of the experiments at $\mathrm{pH} 3$ are in red with dashed connecting lines, those at $\mathrm{pH} 4$ in blue with dotted connecting lines. Symbols represent: $(\bullet)$ TM0.75, TM0.25 or M; (অ) Fe(II), and (४) Fe(III). 
Moreover, dissolved Fe(II) was usually more reactive than dissolved $\mathrm{Fe}(\mathrm{III})$, as is expected from a Fenton process where the reaction between $\mathrm{Fe}(\mathrm{II})$ and $\mathrm{H}_{2} \mathrm{O}_{2}$ is much faster than that between $\mathrm{Fe}(\mathrm{III})$ and $\mathrm{H}_{2} \mathrm{O}_{2}$ [14].

\subsection{Effect of aging time}

The Fenton reactivity of magnetite (and of related materials such as the titanomagnetites) is linked to the occurrence of Fe(II) species at the oxide surface $[15,44]$. Because atmospheric oxygen is able to oxidize Fe(II) to Fe(III), air-exposed magnetite is expected to be inactive in dark conditions, as previously reported [15]. For this reason, the samples studied in this work were stored under $\mathrm{N}_{2}$ atmosphere. However, practical applications in water treatment necessarily require a contact between the solid materials and either air or air-equilibrated aqueous solutions. It is thus important to assess the degree by which the Fenton reactivity of TM0.75, TM0.25 and $\mathrm{M}$ is decreased by atmospheric contact. To this purpose, $30-\mathrm{mL}$ aliquots of the stock suspensions were transferred under atmospheric conditions to vials provided with caps in which a small hole was drilled. These vials were left in contact with air for a scheduled aging time of up to a couple of weeks. The rationale for using drilled caps was to allow for contact with air, and at the same time to minimize contact with solid airborne contaminants. After the aging time, each relevant stock suspension was used as a source of TM0.75, TM0.25 or M in Fenton degradation experiments with phenol

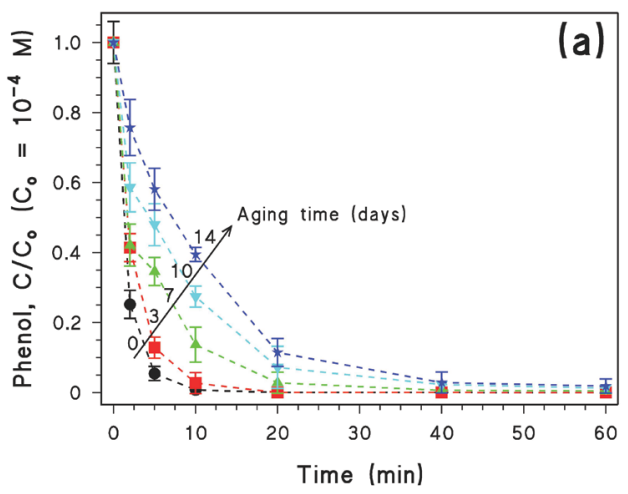

$\left(1.0 \times 10^{-4} \mathrm{M}\right)$ at $\mathrm{pH}$ 3. The results are reported in Fig. 9, showing that all the tested materials underwent some degree of reactivity loss upon aging.

In the case of TM0.75 the degradation of phenol became slower with increasing aging time, but complete phenol degradation could still be achieved after $1 \mathrm{~h}$ reaction time, irrespective of the aging. In contrast, $\mathrm{M}$ and TM0.25 suffered more from aging in air, and their ability to degrade phenol was considerably hampered.

It is also interesting to compare the degradation of phenol by the three materials at zero aging time with that reported in Fig. 2 for $\mathrm{pH} 3$, in which fresh stock suspensions were also used. The conditions were exactly the same in the two cases, except that the experiments of Fig. 9 were carried out after some months in which the stock suspensions had been stored under $\mathrm{N}_{2}$ atmosphere (in which case, one cannot exclude some degree of surface oxidation caused by $\mathrm{O}_{2}$ traces). One can see that TM0.75 retained its reactivity, while some reactivity loss was observed with TM0.25 and M. Because of the higher initial $\mathrm{Fe}(\mathrm{II})$ content in TM0.75 compared with the other materials (see Table 1 and Fig. 5), TM0.75 would still have enough Fe(II) to induce phenol degradation even after air exposure. This issue might explain the better behavior of air-aged TM0.75, compared with $\mathrm{M}$ and TM0.25 that underwent the same treatment. The occurrence of sufficiently elevated amounts of reduced Fe species seems to be important in the preservation of the Fenton reactivity upon air exposure, as previously reported in the case of zero-valent iron [28].

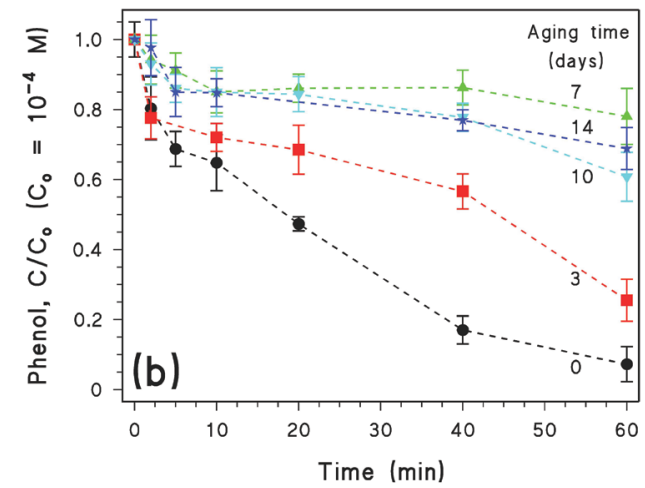

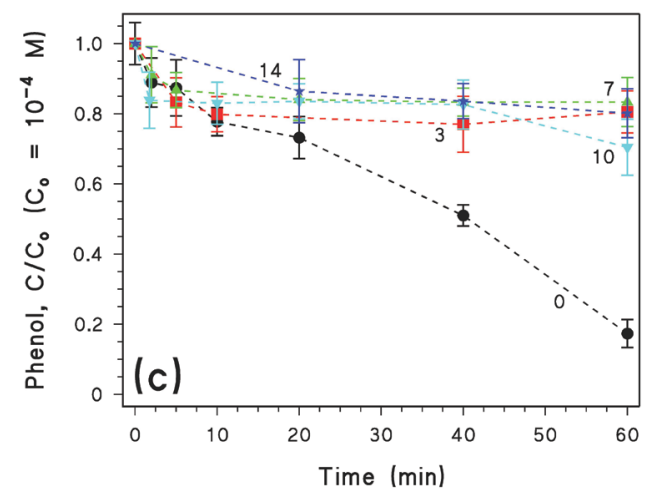

Fig. 9. Time trends of phenol $\left(1.0 \times 10^{-4} \mathrm{M}\right)$ at $\mathrm{pH} 3$, in the presence of $\mathrm{H}_{2} \mathrm{O}_{2}\left(1.0 \times 10^{-3} \mathrm{M}\right)$ and (a) TM0.75, (b) TM0.25 and (c) M (all at $\left.0.1 \mathrm{~g} \mathrm{~L}^{-1}\right)$ at different aging times (the aging times in days are reported near each degradation curve). 


\section{Conclusions}

The studied titanomagnetites (TM0.75 and TM0.25) showed significant Fenton reactivity in the dark toward the degradation of phenol. All the investigated materials (TM0.75, TM0.25 as well as M, the reference magnetite) were active in acidic solution and showed an optimum $\mathrm{pH}$ of 3 , which is typical of the Fenton reaction. Phenol degradation became slower and incomplete at $\mathrm{pH} 4$, and only in the case of $\mathrm{M}$ it was possible to find conditions of substrate and $\mathrm{H}_{2} \mathrm{O}_{2}$ concentration that allowed for complete degradation at $\mathrm{pH} 4$. In contrast, it was not possible to achieve complete phenol degradation at $\mathrm{pH} 4$ in the presence of TM0.75 or TM0.25. However, phenol degradation at $\mathrm{pH} 3$ (and at $\mathrm{pH} 4$ in the case of $\mathrm{M}$ ) could be achieved at low catalyst loading and low $\mathrm{H}_{2} \mathrm{O}_{2}$ concentration, which allows for the reaction to be carried out under mild conditions.

Fe leaching was higher at $\mathrm{pH} 3$ than at $\mathrm{pH} 4$, and in both cases the dissolved Fe species played a significant role in the Fenton process. For actual operation at both $\mathrm{pH}$ values one would need a neutralization procedure after treatment, which would cause Fe precipitation and require a further sedimentation step. However, precipitation would at the same time lower the dissolved Fe concentration in the discharged wastewater. In view of potential applications, Fe occurrence and precipitation could be a problem in the case of the tertiary treatment of urban wastewater because of the need of an additional step before eventual discharge, but it could even become an advantage with some industrial wastes where $\mathrm{Fe}$ addition is required to induce coagulation phenomena [45].

Hydrogen peroxide was only partially consumed in the reaction. Depending on the type of wastewater to be treated, this could be either a drawback due to the $\mathrm{H}_{2} \mathrm{O}_{2}$ toxicity to bacteria (causing potential problems to a possible biological treatment step after the Fenton one), or even an advantage because of the $\mathrm{H}_{2} \mathrm{O}_{2}$ disinfecting capabilities. As far as stability upon contact with air is concerned, TM0.75 was the studied material that best retained the Fenton reactivity. A possible explanation is that TM0.75 has higher Fe(II) content compared with TM0.25 and M. This fact is potentially important in the application field, because it would decrease the requirements for storage under inert atmosphere. Considering that TM0.75

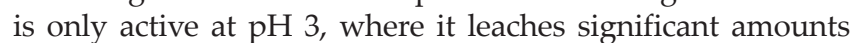
of iron, its use might be of some interest for the treatment of industrial wastewaters that are already acidic, and that require a coagulation step for colloid removal. In this case one could exploit the low operational $\mathrm{pH}$ of TM0.75, while Fe sedimentation after the neutralization step would become an advantage.

\section{Acknowledgements}

DV acknowledges financial support by University of Torino and Compagnia di San Paolo (project CSTO168282ABATEPHARM). The same source provided funding for SB's bursary.

\section{References}

[1] J. Rockström, M. Falkenmark, L. Karlberg, H. Hoff, S. Rost, D. Gerten, Future water availability for global food production: the potential of green water for increasing resilience to global change, Water Resour. Res., 45 (2009) 1-16.
[2] K. Ikehata, M.G. El-Din, Degradation of recalcitrant surfactants in wastewater by ozonation and advanced oxidation processes: a review, Ozone-Sci. Eng., 26 (2004) 327-343.

[3] L.M. Bellotindos, A.T. Chang, M.C. Lu, Degradation of acetaminophen by different Fenton processes, Desal. Wat. Treat., 56 (2015) 1372-1378.

[4] M.R.D. Khaki, M.S. Shafeeyan, A.A.A. Raman, W.M.A. Wan Daud, Evaluating the efficiency of nano-sized $\mathrm{Cu}$ doped $\mathrm{TiO}_{2} /$ $\mathrm{ZnO}$ photocatalyst under visible light irradiation, J. Mol. Liq., 258 (2018) 354-365.

[5] M.R.D. Khaki, M.S. Shafeeyan, A.A.A. Raman, W.M.A. Wan Daud, Enhanced UV-Visible photocatalytic activity of $\mathrm{Cu}$-doped $\mathrm{ZnO} / \mathrm{TiO}_{2}$ nanoparticles, J. Mater. Sci. - Mater. Electron., 29 (2018) 5480-5495.

[6] M.R.D. Khaki, M.S. Shafeeyan, A.A.A. Raman, W.M.A. Wan Daud, Application of doped photocatalysts for organic pollutant degradation - A review, J. Environ. Manage., 198 (2017) 78-94.

[7] C. Comninellis, A. Kapalka, S. Malato, S.A. Parsons, I. Poulios, D. Mantzavinos, Advanced oxidation processes for water treatment: advances and trends for R\&D, J. Chem. Technol. Biotechnol., 83 (2008) 769-776.

[8] S. Gligorovski, R. Strekowski, S. Barbati, D. Vione, Environmental implications of hydroxyl radicals $\left({ }^{\circ} \mathrm{OH}\right)$, Chem. Rev., 115 (2015) 13051-13092.

[9] H. Zou, W. Ma, Y. Wang, A novel process of dye wastewater treatment by linking advanced chemical oxidation with biological oxidation, Arch. Environ. Prot., 41 (2015) 33-39.

[10] S. Harimurti, B.K. Dutta, I.F.B.M. Ariff, S. Chakrabarti, D. Vione, Degradation of monoethanolamine in aqueous solution by Fenton's reagent with biological post-treatment, Water. Air. Soil. Pollut., 211 (2010) 273-286.

[11] S. Adishkumar, S. Sivajothi, J. Rajesh Banu, Coupled solar photo-fenton process with aerobic sequential batch reactor for treatment of pharmaceutical wastewater, Desal. Wat. Treat., 48 (2012) 89-95.

[12] J.A. Sánchez Pérez, I.M. Román Sánchez, I. Carra, A. Cabrera Reina, J.L. Casas López, S. Malato, Economic evaluation of a combined photo-Fenton/MBR process using pesticides as model pollutant. Factors affecting costs, J. Hazard. Mater., 244245 (2013) 195-203.

[13] S. Esplugas, J. Gimenez, S. Contreras, E. Pascual, M. Rodriguez, Comparison of different advanced oxidation processes for phenol degradation, Water. Res., 36 (2002) 1034-1042.

[14] J.J. Pignatello, E. Oliveros, A. MacKay, Advanced oxidation processes for organic contaminant destruction based on the Fenton reaction and related chemistry, Crit. Rev. Environ. Sci. Tec., 36 (2006) 1-84.

[15] M. Minella, G. Marchetti, E. De Laurentiis, M. Malandrino, V. Maurino, C. Minero, D. Vione, K. Hanna, Photo-Fenton oxidation of phenol with magnetite as iron source, Appl. Catal., B, 154-155 (2014) 102-109.

[16] E. Neyens, J. Baeyens, A review of classic Fenton's peroxidation as an advanced oxidation technique, J. Hazard. Mater., 98 (2003) 33-50.

[17] F.W. Haber, J. Weiss, The catalytic decomposition of hydrogen peroxide by iron salts, Proc. R. Soc. A-Math. Phys. Eng. Sci., 147 (1934) 332-351.

[18] D. Vione, M. Minella, V. Maurino, C. Minero, Indirect photochemistry in sunlit surface waters: photoinduced production of reactive transient species, Chem. - A Eur. J., 20 (2014) 10590-10606.

[19] L.M. Pastrana-Martínez, N. Pereira, R. Lima, J.L. Faria, H.T. Gomes, A.M.T. Silva, Degradation of diphenhydramine by photo-Fenton using magnetically recoverable iron oxide nanoparticles as catalyst, Chem. Eng. J., 261 (2015) 45-52.

[20] S.C.N. Tang, I.M.C. Lo, Magnetic nanoparticles: essential factors for sustainable environmental applications, Water. Res., 47 (2013) 2613-2632.

[21] S.R. Pouran, A.R.A. Aziz, W.M.A. Wan Daud, M.S. Shafeeyan, Effects of niobium and molybdenum impregnation on adsorption capacity and Fenton catalytic activity of magnetite, RSC. Adv., 5 (2015) 87535-87549. 
[22] S.R. Pouran, A. Bayrami, A.R.A. Aziz, W.M.A. Wan Daud, M.S. Shafeeyan, Ultrasound and UV assisted Fenton treatment of recalcitrant wastewaters using transition metal-substitutedmagnetite nanoparticles, J. Mol. Liq., 222 (2016) 1076-1084.

[23] S.R. Pouran, A. Bayrami, A.A.A. Raman, W.M.A. Wan Daud, M.S. Shafeeyan, A. Khataee, Comprehensive study on the influence of molybdenum substitution on characteristics and catalytic performance of magnetite nanoparticles, Res. Chem. Intermed., 44 (2018) 883-900.

[24] S.R. Pouran, A. Bayrami, M.S. Shafeeyan, A.A.A. Raman, W.M.A. Wan Daud, A comparative study on a cationic dye removal through homogeneous and heterogeneous Fenton oxidation systems, Acta. Chim. Slov., 65 (2018) 166-171.

[25] R. Marsac, M. Pasturel, K. Hanna, Reduction Kinetics of Nitroaromatic Compounds by Titanium-Substituted Magnetite, J. Phys. Chem. C., 121 (2017) 11399-11406.

[26] S. Yang, H. He, D. Wu, D. Chen, Y. Ma, X. Li, J. Zhu, P. Yuan, Degradation of Methylene Blue by heterogeneous Fenton reaction using titanomagnetite at neutral $\mathrm{pH}$ values: process and affecting factors, Ind. Eng. Chem. Res., 48 (2009) 9915-9921.

[27] Y. Zhong, X. Liang, Y. Zhong, J. Zhu, S. Zhu, P. Yuan, H. He, J. Zhang, Heterogeneous UV/Fenton degradation of TBBPA catalyzed by titanomagnetite: catalyst characterization, performance and degradation products, Water. Res., 46 (2012) 4633-4644.

[28] M. Minella, E. Sappa, K. Hanna, F. Barsotti, V. Maurino, C. Minero, D. Vione, Considerable Fenton and photo-Fenton reactivity of passivated zero-valent iron, RSC. Adv., 6 (2016) 86752-86761.

[29] X. Xue, K. Hanna, C. Despas, F. Wu, N. Deng, Effect of chelating agent on the oxidation rate of PCP in the magnetite/ $\mathrm{H}_{2} \mathrm{O}_{2}$ system at neutral pH, J. Mol. Catal. A Chem., 311 (2009) 29-35.

[30] J. He, X. Yang, B. Men, D. Wang, Interfacial mechanisms of heterogeneous Fenton reactions catalyzed by iron-based materials: a review, J. Environ. Sci., 39 (2016) 97-109.

[31] G. Busca, S. Berardinelli, C. Resini, L. Arrighi, Technologies for the removal of phenol from fluid streams: a short review of recent developments, J. Hazard. Mater., 160 (2008) 265-288.

[32] G.F. Torres, J.A. Ortega Méndez, D.L. Tinoco, E.D. Marin, J. Araña, J.A. Herrera-Melián, J.M. Doña Rodrígez, J. Pérez Peña, Detoxification of synthetic and real groundwater contaminated with gasoline and diesel using Fenton, photo-Fenton, and biofilters, Desal. Wat. Treat., 57 (2016) 23760-23769.

[33] C.I. Pearce, O. Qafoku, J. Liu, E. Arenholz, S.M. Heald, R.K. Kukkadapu, C.A. Gorski, C.M.B. Henderson, K.M. Rosso, Synthesis and properties of titanomagnetite $\left(\mathrm{Fe}_{3-\mathrm{x}} \mathrm{Ti}_{\mathrm{x}} \mathrm{O}_{4}\right)$ nanoparticles: a tunable solid-state $\mathrm{Fe}(\mathrm{II} / \mathrm{III})$ redox system, J. Colloid. Interface. Sci., 387 (2012) 24-38.
[34] W.B. Fortune, M.G. Mellon, Determination of iron with o-phenanthroline: a spectrophotometric study, Ind. Eng. Chem. Anal. Ed., 10 (1938) 60-64.

[35] L. Li, R.K. Goel, Role of hydroxyl radical during electrolytic degradation of contaminants, J. Hazard. Mater., 181 (2010) 521-525.

[36] E.B. Sandel, Colorimetric Determination of Traces' of Metals, 2nd ed., 1950.

[37] R.K. Adhikamsetty, N.R. Gollapalli, S.B. Jonnalagadda, Complexation kinetics of $\mathrm{Fe}^{2+}$ with 1,10-phenanthroline forming ferroin in acidic solutions, Int. J. Chem. Kinet., 40 (2008) 515-523.

[38] K.A.Riganakos, P.G. Veltsistas, Comparativespectrophotometric determination of the total iron content in various white and red Greek wines, Food. Chem., 82 (2003) 637-643.

[39] J.E. Frew, P. Jones, G. Scholes, Spectrophotometric determination of hydrogen peroxide and organic hydropheroxides at low concentrations in aqueous solution, Anal. Chim. Acta., 155 (1983) 139-150.

[40] X. Xue, K. Hanna, M. Abdelmoula, N. Deng, Adsorption and oxidation of PCP on the surface of magnetite: kinetic experiments and spectroscopic investigations, Appl. Catal. B. Environ., 89 (2009) 432-440.

[41] M. Minella, N. De Bellis, A. Gallo, M. Giagnorio, C. Minero, S. Bertinetti, R. Sethi, A. Tiraferri, D. Vione, Coupling of nanofiltration and thermal Fenton reaction for the abatement of carbamazepine in wastewater, ACS. Omega, 3 (2018) 9407-9418.

[42] R.J. Watts, D. Washington, J. Howsawkeng, F.J. Loge, L. Teel, Comparative toxicity of hydrogen peroxide, hydroxyl radicals, and superoxide anion to Escherichia coli, Adv. Environ. Res., 7 (2003) 961-968.

[43] J.D. Hem, W. Stumm, Stability field diagrams as aids in iron chemistry studies, J. Am. Water. Work. Assoc., 53 (1961) 211-232.

[44] M. Usman, P. Faure, K. Hanna, M. Abdelmoula, C. Ruby, Application of magnetite catalyzed chemical oxidation (Fentonlike and persulfate) for the remediation of oil hydrocarbon contamination, Fuel., 96 (2012) 270-276.

[45] V. Ya, N. Martin, Y.H. Chou, Y.M. Chen, K.H. Choo, S.S. Chen, C.W. Li, Electrochemical treatment for simultaneous removal of heavy metals and organics from surface finishing wastewater using sacrificial iron anode, J. Taiwan. Inst. Chem. Eng., 83 (2018) 107-114. 